\title{
Perang dalam Perspektif Agama
}

\author{
Daniel Ronda
}

\section{Pendahuluan}

Tulisan di majalah TIME 24 Februari 2003 oleh Joe Klein "The Blinding Glare of His Certainty" mempertanyakan antara iman kepercayaan Bush dengan keinginannya yang menggebu-gebu untuk menyerang Irak, walaupun mendapat tantangan dari masyarakat dunia maupun masyarakatnya sendiri. Apalagi kemudian ia menjadikan ayatayat Kitab Suci sebagai alat untuk mengesahkan opininya tentang perlunya menghancurkan terorisme. Tulisan Klein juga mencoba memahami mengapa terjadi perubahan sikap keyakinan di mana sewaktu menjadi Gubernur Texas yang banyak memakai kata kasih dan hati nurani, dan saat ini berbalik sekali waktu akan menyerang Irak. Sekarang bahasa Bush saat ini adalah bahasa arogan dan balas dendam atas serangan. terorisme. Dia menuduh dan berkata, "The terrorists brought this war to us- and now we're takin' back to them." Dia juga berkata kepada para tentara, "We're on the trail, we're smokin' them out we've got "em on the run." Walaupun demikian, kesimpulan yang dibuat Klein terhadap Bush bahwa sikapnya terhadap perang dan balas dendam bukan karena faktor keyakinan imannya yang konservatif. Tetapi agamanya seharusnya bukan hanya membuat seseorang mendapat penghiburan (comfort) dan kekuatan (strength), tetapi seharusnya dalam pengambilan keputusan perang, seorang pemimpin harus melihat agama sebagai sumber untuk mendapatkan hikmat (wisdom) sebelum memutuskan menyerang suatu negara.

Perang juga terjadi di negara kita, di mana TNI memutuskan untuk mengadakan operasi terpadu (terutama militer) terhadap gerakan separatis Aceh atau GAM. Keputusan untuk perang kali ini mendapat dukungan yang luas dari pemerintah, DPR, bahkan dari jajak pendapat di koran sekalipun.

Tulisan ini hendak mempertanyakan bagaimana agama bersikap terhadap perang. Atau. Perang pada satu sisi ditentang, karena dalam Kitab Suci yaitu adanya larangan "Jangan membunuh", namun pada prakteknya perang terus ada di dalam sepanjang sejarah manusia. Memang perang adalah realitas sejarah dan selalu akan ada perang dalam 
peradaban manusia. Suatu hal yang mungkin tidak bisa dielakkan. Namun ada hal lain yang perlu selalu perlu dipertanyakan adalah apakah benar agama memberikan legitimasi atas perang?

\section{Tiga Pandangan Tentang Perang}

Dalam agama (termasuk Kristiani), setidaknya ada tiga pandangan terhadap perang. ${ }^{1}$ Pertama adalah pandangan aktivisme, yang berpendapat bahwa setiap orang harus berpartisipasi dalam perang yang diperintahkan oleh negara. Alasannya adalah bahwa pemerintah adalah dibentuk oleh Tuhan, sehingga kewajiban rakyat mendukung perang yang dilakukan oleh negara. Ayat suci yang dipakai landasan adalah Roma 13:1-7. Di sini negara telah diberi wewenang untuk memegang "pedang". Konteksnya difahami sebagai ketaatan kepada pemerintah harus dibuktikan dengan sikap tunduk atas keputusan pemerintah, yang misalnya memerintahkan perang. Apalagi pemerintah diberi wewenang untuk membalaskan murka Allah.

Argumen lain untuk mendukung perang adalah argumen filosofis yaitu bahwa tanpa pemerintah, sebenarnya manusia tidak dapat eksis. Lagipula pemerintah adalah pelindung dan orang tua. Keberadaan kita sejak lahir adalah karena bantuan, subsidi, serta perlindungan dari pemerintah. Jika tidak demikian maka dipastikan negara bukanlah suatu negara, karena tidak adanya perlindungan hukum. Jadi kesimpulannya, bila pemerintah adalah pelindung dan "orang tua", maka adalah kewajiban mendukung perang tanpa harus mempertanyakannya apakah benar atau tidak. Pandangan ini tentu tidak mayoritas dalam pengikut agama, namun masih nampak dalam radikalisme agama.

Kedua, adalah pandangan pasifisme, yang memiliki pandangan berlawanan dengan aktivisme bahwa semua perang itu salah. Itu sebabnya semua aktivitas perang harus dihentikan, karena alasannya di dalam Kitab Suci, perintah perang bukan merupakan perintah langsung namun hanya sejarah bagaimana pengikut agama melegitimasi perang dengan mengatasnamakan Tuhan. Perintah kitab suci menurut pandangan ini sudah jelas yaitu jangan membunuh (Kel. 20:13), dan juga sabda Tuhan Yesus untuk tidak membalas orang yang berbuat jahat kepada kita (Matius 5:39).

Pertanyaan tentunya adalah bagaimana dengan perintah perang yang ada di dalam Alkitab? Bagi penganut pasifis, perintah itu bukan perintah sesungguhnya tetapi itu bukan perang manusia. Itu adalah ${ }^{1}$ Lihat bahasan lebih lanjut dan lengkap pada tulisan Norman Geisler,
Etika Kristen: Pilihan dan Isu (Malang: SAAT, 2000), 274-305 
benar, yaitu secara proporsional, bersikap diskriminatif yaitu hanya kepada sasaran militer dan menghindari jatuhnya korban sipil. Hasilnya, harus cepat tuntas dengan perkiraan yang tepat dan maksimal.

Di samping itu perlakuan dan perlindungan terhadap sipil harus dijaga serta dihormati. Itu sebabnya pembunuhan terhadap penduduk sipil adalah sangat dilarang. Musuh adalah mereka yang melawan, tetapi begitu yang bersangkutan menyerah, maka tidak bisa lagi dikategorikan sebagai musuh. Tawanan perang pun harus diperlakukan secara benar. Bila unsur-unsur ini tidak dilakukan, maka perang yang adil patut dipertanyakan.

Namun pertanyaan berikutnya yang menyimpan persoalan adalah siapakah yang menentukan suatu perang yang adil? Secara global seharusnya PBB, mengingat banyak ketidakadilan seperti pendudukan suatu negara kepada negara lainnya yang berbuntut kepada pembalasan yang tidak pernah habis-habisnya. Tetpi kenyataannya PBB pun saat ini di ujung tanduk, karena bagaimana bila ada negara yang tidak tunduk kepada resolusi PBB. Persoalan ini selalu mengemuka karena persepsi tentang kebenaran sudah terpolarisasi sehingga penafsiran telah dibungkus dengan bias agama, solidaritas daerah atau regional, atau etnis. Belum lagi dampak krisis yang akan ditimbulkan dalam perang, karena negara-negara makin bergantung satu dengan yang lainnya.

Menjawab persoalan di atas seharusnya yang dapat mengukur perang itu adil dan benar bila berdasarkan kebenaran dari hati nurani rakyat, dan hal ini yang mesti didengar pemerintah sebagai salah satu kebenaran dalam mempertimbangkan perang. Pemerintah harus melibatkan semua pihak dalam memutuskan perang yang adil dan benar. Namun ini harus selalu menjadi pilihan terakhir, karena pada dasarnya misi Kristus adalah pembawa damai.

\section{Refleksi:}

Peran agama untuk membawa kedamaian harusnya bukan hanya muncul pada saat krisis perang muncul, namun dalam tindakan keseharian yaitu dimulai dari hal-hal yang kecil dalam komunitas yang paling di bawah. Refleksi iman harus nampak dalam kehidupan seharihari dalam mewujudkan kasih dan damai.

Perang selalu berdampak buruk terhadap kehidupan manusia, di mana tangis dan air mata hampir selalu diikuti dengan dendam dan aksi pembalasan. Agama harus menjadi wisdom bagi pemimpinpemimpin negara dalam memutuskan perang, dan tidak menjadikan agama alat legitimasi untuk memerangi negara lain. 
perang Allah, di mana Allah memenangkan perang lewat mujizat dan campur tangannya sendiri dalam memberi kemenangan.

Namun ada juga alasan yang masuk akal untuk menolak perang adalah karena dampak yang diakibatkannya yaitu faktor sosial. Bahwa peperangan selalu berdampak buruk kepada masyarakat, misalnya akan muncul bahaya kelaparan, janda dan anak yatim piatu, cacat, kehancuran ekonomi, dsb. Hal ini dapat dilihat di Vietnam, Kamboja dalam dekade yang lalu, di mana perlu berpuluh-puluh tahun untuk memulihkan keadaan seperti sediakala. Itu sebabnya kaum pasifis, selalu memperjuangkan gerakan non-violence (anti-kekerasan) dan non-resistance (anti-perlawanan). Ajaran anti kekerasan bukan hanya berpedoman pada agama atau ayat-ayat Alkitab, tetapi ada juga gerakan anti perang berdasarkan faktor humanistik seperti gerakan anti-kekerasan oleh Mahatma Gandhi, Dalai Lama, dsb.

Ketiga, adalah pandangan selektivisme, di mana perang harus dilihat dulu mana perang yang adil dan mana yang tidak dapat dilakukan. Alasannya tidak semua perang dapat dibenarkan, namun dapat diizinkan perang bila untuk keadilan. Kuncinya adalah perang yang adil atau just war. Alasannya adalah tidak semua perintah perang yang dilakukan pemerintah itu adil. Dan ada di Alkitab, di mana bisa dilakukan pembangkangan sosial terhadap pemerintah seperti kisah dalam Daniel 3, di mana tokoh-tokoh iman menolak untuk taat kepada pemerintah.

Umumnya secara mayoritas kekristenan menerima konsep ini. Kelompok agama lain yang moderat menganut pandangan seperti ini entah itu Kristen, Islam, Hindu, Buddha dan agama lainnya.

Ada setidaknya tujuh prinsip perang yang dibenarkan yaitu perang secara formal dengan alasan yang benar, sebagai alat atau usaha yang terakhir, untuk kebenaran dan keadilan serta kebaikan, dengan memiliki itikad yang baik, caranya harus bertanggung jawab,meminimalisasi korban sipil, dan cepat diselesaikan dengan keberhasilan yang maksimal.

\section{Perang yang Benar dan Adil, Apakah Ada?}

Banyak yang masih mempertanyakan apakah perang yang adil itu ada? Siapakah yang menentukan suatu itu adil? Istilah perang dengan alasan yang benar maksudnya adalah perang dengan maksud pembelaan diri (defensive war), dan bukan agresi. ${ }^{2}$ Cara perang juga harus ${ }^{2}$ Helmut Thielicke, Theological Ethics: Foundations (Grand Rapids, Mich.:
Eerdmans, 1986/reprinted), 412. 